\title{
Temporal changes in bacterial rRNA and rRNA genes in Delaware (USA) coastal waters
}

\author{
B. J. Campbell, L. Yu, T. R. A. Straza, D. L. Kirchman* \\ University of Delaware, School of Marine Science and Policy, 700 Pilottown Road, Lewes, Delaware 19958, USA
}

\begin{abstract}
The diversity and abundance of bacterial 16S rRNA genes (rDNA) and associated 16S rRNA were assessed to examine community structure and potential activity in a 2 yr seasonal study of marine surface waters along the Delaware (USA) coast. The majority of the ribotypes appearing as rRNA or rDNA were present at least $50 \%$ of the time, and their variation over time was less than that of most biotic and abiotic factors. Even though there were no predictable seasonal patterns in community structure, environmental parameters explained between 40 and $50 \%$ of the observed variation in community structure. In general, summer communities correlated positively with temperature, light, bacterial production, and phosphate levels, while winter communities correlated with dissolved organic carbon concentrations. The abundance of 3 select ribotypes (SAR11, a Cytophaga subgroup, SAR116-like) varied some over time as measured by quantitative PCR (qPCR). The SAR11 clade was 10 times more abundant than the other 2 groups. However, the 16S rRNA to rDNA ratios, as measured by qPCR and reverse transcription-qPCR, varied greatly over time and were highest in the SAR11 population and the Cytophaga subgroup. The rRNA to rDNA ratio of the Cytophaga subgroup and SAR116-like group significantly correlated with some environmental parameters. Taken together, these results suggest that the community composition of the major members does not change much over time, but individual members do vary in abundance and activity and can be influenced by environmental factors.
\end{abstract}

KEY WORDS: Ribotype $\cdot$ Activity $\cdot$ Quantitative PCR $\cdot 16 \mathrm{~S}$ rRNA

\section{INTRODUCTION}

Several studies have explored the structure of marine bacterial communities, but few have examined changes in structure over time and have attempted to link these changes to biotic or abiotic factors (Fuhrman et al. 2006, Alonso-Sáez et al. 2007, Pommier et al. 2007). The response of the total community to these factors depends in part on whether individual phylotypes making up the community are active. While much is known about the activity of the total microbial community and of some large bacterial groups, such as the Alphaproteobacteria or Cytophaga (Cottrell \& Kirchman 2000, Ducklow 2000, Alonso-Sáez \& Gasol 2007), little is known about the activity of individual ribotypes. Previous studies have examined whether an individual ribotype is potentially active from the pres- ence of its 16S rRNA as deduced from 16S rRNA cDNA gene libraries and fingerprinting techniques (Schafer et al. 2001, Troussellier et al. 2002, Gentile et al. 2006, Lami et al. 2009) and by labeling of rRNA genes in bacteria incorporating bromodeoxyuridine (Pernthaler et al. 2002b, Hamasaki et al. 2007). However, it is not clear whether these qualitative and semi-quantitative methods are adequate for completely describing community structure and for understanding how communities change in response to biotic and abiotic processes.

Estimates of active bacteria in the ocean range from $1 \%$ or less of the community to greater than $90 \%$, depending on the method used (del Giorgio \& Gasol 2008). For instance, although the SAR11 clade is one of the most abundant bacterial groups in the oceans (Morris et al. 2002, Giovannoni \& Stingl 2005, Malmstrom et al. 2005), the slow growth rate of Pelagibacter 
ubique, the model organism in this group, in the laboratory raises questions about growth rates and activity of it and other SAR11 bacteria in the ocean (Rappé et al. 2002, Giovannoni et al. 2005b). A study using the thymidine analog bromodeoxyuridine has suggested that this group is not actively growing (Hamasaki et al. 2007). In contrast, other techniques such as microautoradiography combined with fluorescence in situ hybridization (Micro-FISH) and flow sorting of CTC+ cells suggest that SAR11 bacteria are growing and are active, comparable to other bacteria in the oceans (Malmstrom et al. 2004, 2005, Longnecker et al. 2005). Additionally, SAR11 is a large clade, made up of several members adapted to different conditions (Carlson et al. 2009), and as such, measured activities of the entire clade are averages of all subgroups present in the selected environment.

Microbial community structure and presumably activity are hypothesized to vary seasonally, because of biotic and abiotic environmental factors (Fuhrman et al. 2006, Teira et al. 2008). Coastal marine ecosystems are influenced by these factors, especially during times of phytoplankton blooms, physical mixing of estuarine and marine waters, and nutrient inputs from terrestrial sources. Several recent studies have addressed temporal shifts in microbial community structure in coastal marine systems (Ghiglione et al. 2005, Fuhrman et al. 2006, Mary et al. 2006, Alonso-Sáez et al. 2007, 2008). With a few exceptions, most used DNA fingerprinting techniques to demonstrate seasonal variation in bacterioplankton community structure over short periods of time, generally 1 yr (Ghiglione et al. 2005, Alonso-Sáez et al. 2007, 2008). Few studies have combined measures of seasonal microbial activity and/or structure, especially of the most abundant groups, such as SAR11 (Morris et al. 2005, Fuhrman et al. 2006, Carlson et al. 2009).

The goals of the present project were to assess the seasonal structure and activity of individual bacterial ribotypes in a coastal marine ecosystem. Free-living bacteria were collected monthly for 2 yr from a coastal site just outside the Delaware Bay. This site may be influenced by estuarine contributions, especially after rain and wind events (Whitney \& Garvine 2005). We used denaturing gradient gel electrophoresis (DGGE) to analyze the structure of bacterial communities via the 16S rRNA gene (rDNA) and 16S rRNA and compared them with a large set of environmental parameters. Quantitative PCR of the rDNA gene and rRNA was also done on 1 abundant (SAR11) and 2 less abundant (SAR116-like and a Cytophaga subgroup) groups of bacteria to follow their abundance and activity over time. We found significant temporal differences in activity as measured by the ratio of rRNA to rDNA copies even though overall community structure was stable.

\section{MATERIALS AND METHODS}

Sample site, collection, and characterization. Surface water samples were collected from a site beyond the mouth of the Delaware Bay $\left(38^{\circ} 50.935^{\prime} \mathrm{N}\right.$, $\left.75^{\circ} 06.456^{\prime} \mathrm{W}\right)$. A variety of standard oceanographic properties were measured, including water temperature, salinity, light intensity (photosynthetically active radiation, PAR), light attenuation, Secchi depth, abundance of total bacterioplankton, aerobic anoxygenic phototrophs (AAP), cell size, leucine incorporation via the microcentrifugation protocol, chlorophyll a (chl a) concentration, and nutrients $\left(\mathrm{NO}_{3}, \mathrm{NH}_{4}, \mathrm{PO}_{4}, \mathrm{Si}\right.$, dissolved organic nitrogen [DON], and dissolved organic carbon [DOC]) as described previously (Preen \& Kirchman 2004, Kirchman et al. 2005, Cottrell et al. 2006, Michelou et al. 2007). Bacterial abundances and cell size were determined via microscopy after DAPI staining, and AAP abundances via bacteriochlorophyll a autofluorescence microscopy. Samples for nucleic acids were filtered through $0.8 \mu \mathrm{m}$ pore size filters before collection on $0.22 \mu \mathrm{m}$ Durapore membranes. Filters were frozen at $-80^{\circ} \mathrm{C}$ in $1 \mathrm{ml}$ of CTAB buffer (Dempster et al. 1999) until nucleic acids were extracted.

Nucleic acid extraction and DGGE. Total nucleic acids were extracted using a modified CTAB extraction protocol (Dempster et al. 1999) with 2 chloroform extractions instead of 1. DNA was separated from RNA via RNAase I digestion, and RNA was isolated from total nucleic acid preparation via DNAase I digestion of the sample as outlined in the manufacturer's protocol (Ambion). DNA or RNA was quantified via a Picogreen or Ribogreen assay, respectively, as recommended by the manufacturer (Invitrogen). Approximately $50 \mathrm{ng}$ of RNA from each sample were reverse transcribed into cDNA with random primers using the Superscript First-Strand synthesis system for RT-PCR (Invitrogen). All samples were tested for the presence of contaminating DNA by PCR as described below.

DNA and cDNA ( 1 ng each) were subjected to PCR with standard 16S rRNA gene primers and conditions for DGGE, where the $5^{\prime}$ primer contained a $40 \mathrm{bp} \mathrm{GC}$ clamp (Kirchman et al. 2001, Castle et al. 2006). To minimize plateau effects and PCR artifacts, samples were amplified in triplicate and pooled. In addition, cycle numbers were optimized to stop in the linear portion of the amplification (generally, 23 cycles for cDNA, 30 for DNA). Pooled amplicons were quantified by a picogreen assay, and $100 \mathrm{ng}$ of each product were run on a 25 to $55 \%$ denaturing gradient gel at $150 \mathrm{~V}$ for $5 \mathrm{~h}$. Gels were stained with SYBR gold as recommended by the manufacturer (Invitrogen) and visualized using a Kodak Gel Logic 100 imaging system. Gel images were analyzed for band presence and relative intensi- 
ties of individual bands by the Kodak and Phoretix (Non-linear Dynamics) systems and modified manually as necessary. Identical bands were matched between gels by the use of reference lanes and comparison to 2 additional gels that contained either all the DNA or RNA samples from each original gel. Cluster analysis was performed in PAST (Hammer et al. 2001) using a Raup-Crick similarity coefficient on a band presence/ absence matrix. Relative intensities were used for comparison of relative amounts of rRNA and rDNA genes from some major ribotypes.

DGGE bands were directly sequenced after reamplification as described previously (Campbell \& Cary 2001). Those sequenced bands containing more than 1 ribotype were subsequently cloned into a TA-TOPO vector. Approximately 10 clones from each reaction were sequenced. Sequences were analyzed in the web-based Greengenes database program, with both alignment and classification methods (DeSantis et al. $2006 a, b)$ because of the short region sequenced (183 \pm $19 \mathrm{bp}$ ), and compared to 16S rRNA gene sequences obtained from the Cape May subset of the Global Ocean Sampling (GOS) dataset sequences (Rusch et al. 2007) analyzed with the same methods. DGGE band sequences were assigned the GenBank nucleotide accession numbers FJ611231 to FJ611274.

Estimates of ribosomal and 16S rRNA gene abundance. Initially we tried amplifications with PCR primers specific for 4 groups of bacteria found in our samples: SAR11, SAR86, the Cytophaga subgroup (Microscilla cluster), and the SAR116-like group. We developed primers for the latter 2 groups for this study, while the former 2 had previously developed primers (Suzuki et al. 2001). Clones were generated and sequenced after test amplifications on at least 2 samples with the optimized primer sets. Three of the 4 primer sets were specific enough $(>95 \%$ of clones were in the specific group), but the SAR86 primers were not, and were not further pursued. To verify primer specificity, QPCR primer pairs were used in PCR to amplify 16S rRNA genes from a mixture of 2 samples. PCR amplification conditions were as outlined below, except no dissociation step was used. PCR products were cloned and sequenced following standard protocols. Ten clones were analyzed from each primer set. When aligned to the reference sequences, all fell within the expected group. qPCR clone sequences were assigned the GenBank nucleotide accession numbers FJ611275 to FJ611317.

Plasmid clones for positive controls and qPCR standard curves were identified from either a previous 16S rRNA gene clone library (SAR11, OCS143, U75266; Rappé et al. 2000), a 16S rRNA library generated from the free-living fraction with Cytophagaspecific primers (Kirchman et al. 2003), or a clone library of a specific DGGE band (SAR116-like). Primers for these 2 groups, designed based on sequences obtained from 16S rRNA clone libraries, DGGE bands, and GenBank database hits, are: SAR116_512F GGT GAA GAT GAT GAC GGT ANC CA; SAR116_6661R GGG GMT TTC ACG CCT AAC; CF316F (Kirchman et al. 2003) and CF subgroup 663R ACC GTC AGT TRT CTA CAC GTA GA. Plasmids were isolated and readied for qPCR as described previously (Campbell et al. 2008). Standard reactions containing linearized plasmid contained approximately $10^{1}$ to $10^{6}$ copies reaction $^{-1}$. All standard curves were linear within the ranges tested. Either DNA or RNA from the indicated sample was

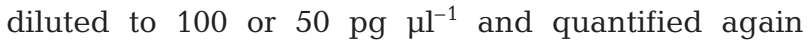
using the Picogreen or Ribogreen assay, respectively.

Quantitative PCR was performed in triplicate or quadruplicate with $1 \mu \mathrm{l}$ of diluted DNA or RNA in a final volume of $12.5 \mu \mathrm{l}$ using the Stratagene Brilliant SYBR green mix (DNA) or the SuperScript III Platinum One Step qRT-PCR kit (Invitrogen) on the ABI 7500, and PCR conditions of $95^{\circ} \mathrm{C}$ for $10 \mathrm{~min}$, followed by 40 cycles of amplification at $95^{\circ} \mathrm{C}$ for $15 \mathrm{~s}$, the indicated annealing temperature for $45 \mathrm{~s}$, and $72^{\circ} \mathrm{C}$ for $45 \mathrm{~s}$, with a final dissociation step. Annealing temperatures for SAR11, the SAR116-like group, and the Cytotophaga subgroup were 58,59 , and $59^{\circ} \mathrm{C}$, respectively. Final primer concentrations were $0.2 \mu \mathrm{M}$. Only single peaks were observed in the dissociation curves from both the standards and samples, indicating specific amplification with each set of primers. Average amplification efficiencies were as follows: SAR11 $=100 \%$; Cytophaga subgroup $=92 \%$; and SAR116-like group $=$ $99 \%$.

The number of Cytophaga subgroup 16S rRNA gene copies was estimated to be 5 based on the genome content of finished and unfinished genomes within the Bacteroidetes phylum present in the NCBI database. Ten genomes were examined for 16S rRNA gene copy number, including the finished genomes of Flavobacterium johnsoniae (6 16S rRNAs), Bacteroides thetaiotaomicron (5), Gramella forsetii (3), F. psychrophium (6), B. fragilis (6), C. hutchinsonii (3), and B. vulgatus (7) and the unfinished genomes of Dakdonia sp. MED134 (3), Polaribacter irgensii (3), and Tenacibaculum sp. MED152 (3). We estimated the number of SAR116-like copies to be 1 because there is no current genome information for this group, although a cultured representative was recently obtained (Stingl et al. 2007) and another is currently being sequenced (Alphaproteobacterium IMCC1322).

Abundance of the SAR11 clade and all bacteria. Catalyzed reporter deposition fluorescent in situ hybridization (CARD-FISH; Pernthaler et al. 2002a) was performed on surface water samples using methods 
previously described (Straza et al. 2009). Briefly, cells were fixed, filtered onto $0.2 \mu \mathrm{m}$ polycarbonate filters, embedded with $0.1 \%$ agarose, and treated with lysozyme. Filters were hybridized with horseradish peroxidase-labeled oligonucleotide probes (Biomers: SAR11 clade [SAR11-441r], all bacteria [EUB338], and a negative control; Amann et al. 1990, Karner \& Fuhrman 1997, Morris et al. 2002), stained with cyanine-3-labeled tyramides (Perkin Elmer), counterstained with 4'-6-diamidino-2-phenylindole, and counted (Cottrell \& Kirchman 2003). Data reported are the percentages of total DAPI-stained cells that were also Cy3-stained.

Statistical analyses. Pearson's correlation test was done to determine significant relationships between environmental parameters. Canonical correspondence analysis (CCA) was performed in PC-ORD (McCune \& Grace 2002) to assess the relationships between operational taxonomic unit (OTU) presence/absence and environmental parameters. To examine a modal versus linear response, CCA results were compared to redundancy analysis (RDA), estimated in Polynomial RDACCA, using the standard RDA based on multiple linear regression (Makarenkov \& Legendre 2002). For $\mathrm{CCA}$, the conditions selected were the default parameters of (1) axis scores were centered and standardized to unit variance; (2) axes were scaled to compromise representation of species and date; and (3) scores for graphing date were linear combinations of environmental data. The intraset correlations of ter Braak (1986) were also used in CCA. The Mantel test and subset tests were also done in $\mathrm{R}$ (vegan package) on these same samples (Legendre \& Legendre 1998). Nonmetric multidimentional scaling (MDS) was performed in PC-ORD with 500 iterations, and a 3-dimensional plot resulted, with a stress value of 14.9 (McCune \& Grace 2002). Abundance estimates of SAR11 or total bacteria by CARD-FISH (Pernthaler et al. 2002a) (expressed as percent of total prokaryotes), and relative intensities of DGGE fragments were arcsine transformed prior to multiple regression analyses.

\section{RESULTS}

Analyses of 2 yr of environmental data from just outside the mouth of the Delaware Bay indicated variable levels of abiotic and biotic factors. Some parameters displayed a consistent temporal pattern, e.g. temperature and leucine incorporation, and, to a lesser extent, chl a (Fig. 1). Temperature and leucine incorporation peaked both years in the late summer. Chl a concentrations peaked several times over the course of the $2 \mathrm{yr}$, with values above $15 \mu \mathrm{g} \mathrm{l}^{-1}$ in March 2006 and February 2007, and minor peaks $\left(\sim 8 \mu^{-1} \mathrm{l}^{-1}\right)$ in Septem-

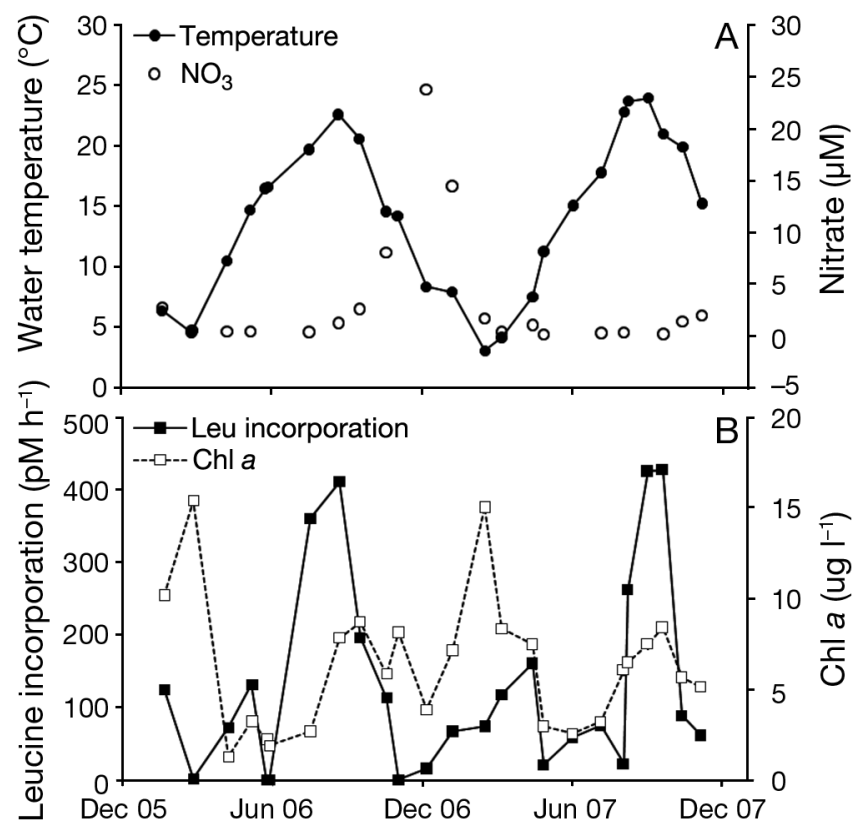

Fig. 1. Seasonal dynamics of environmental factors in Delaware coastal waters over time. (A) temperature and nitrate concentration; (B) chl a concentration and leucine incorporation rates

ber of both years and in November 2006 (Fig. 1). While the majority of the nitrate values were $<3 \mu \mathrm{M}$, there was one large peak in nitrate in December 2006 of 24 $\mu \mathrm{M}$ (Fig. 1). Other properties did not vary consistently over time (data not shown).

\section{Bacterial community structure in Delaware coastal waters}

DGGE was used to follow changes in the 16S rRNA genes (rDNA) of bacterial communities over time. The number of major community members as measured by the number of bands in the DGGE samples ranged from 15 to 29 (Table 1). A large number of recurrent ribotypes was present in the community (Fig. 2). Five ribotypes were always present, 12 ribotypes (rDNA) were present in over $50 \%$ of the months, and 24 were found at least $20 \%$ of the time. Non-metric MDS of OTU presence/absence revealed no identifiable seasonal patterns, but the 2 yr were distinct (Fig. 3). Cluster analysis (UMPGA) or ordination techniques (principal coordinate analysis) yielded similar results (data not shown).

A number of the abundant DGGE bands were sequenced to identify the major community members. Some major members included SAR11, SAR86, and SAR116 (Table 2). Other abundant or infrequent members of the community were similar to previously 
described marine bacterioplankton found in coastal and estuarine waters, including Bacteroidales, Flavobacteriales, Prochlorales, Alphaproteobacteria, Azospirillales, Burkholderiales, Alteromonadales, Chromatiales, Enterobacteriales, SUP05, Vibrionales, and

Table 1. Numbers of rRNA and rDNA ribotypes determined via DGGE analysis in Delaware coastal seasonal samples. Dates given as mm/dd/yyyy

\begin{tabular}{|c|c|c|c|}
\hline \multirow{2}{*}{ Date } & \multicolumn{2}{|c|}{ No. of ribotypes } & \multirow{2}{*}{ RNA:DNA } \\
\hline & DNA & RNA & \\
\hline $2 / 7 / 2006$ & 15 & 10 & 0.67 \\
\hline $3 / 9 / 2006$ & 23 & 17 & 0.74 \\
\hline $5 / 18 / 2006$ & 16 & 14 & 0.88 \\
\hline $6 / 5 / 2006$ & 15 & 12 & 0.80 \\
\hline $7 / 27 / 2006$ & 20 & 17 & 0.85 \\
\hline $8 / 31 / 2006$ & 22 & 10 & 0.45 \\
\hline $9 / 25 / 2006$ & 17 & 10 & 0.59 \\
\hline $10 / 27 / 2006$ & 21 & 19 & 0.90 \\
\hline $12 / 14 / 2006$ & 21 & 18 & 0.86 \\
\hline $1 / 11 / 2007$ & 21 & 16 & 0.76 \\
\hline $2 / 22 / 2007$ & 19 & 14 & 0.74 \\
\hline $3 / 14 / 2007$ & 24 & 15 & 0.63 \\
\hline $4 / 20 / 2007$ & 29 & 17 & 0.59 \\
\hline $5 / 3 / 2007$ & 27 & 16 & 0.59 \\
\hline $6 / 7 / 2007$ & 21 & 18 & 0.86 \\
\hline $7 / 11 / 2007$ & 27 & 19 & 0.70 \\
\hline $8 / 7 / 2007$ & 26 & 14 & 0.54 \\
\hline $9 / 5 / 2007$ & 21 & 16 & 0.76 \\
\hline $10 / 16 / 2007$ & 25 & 14 & 0.56 \\
\hline $11 / 8 / 2007$ & 26 & 20 & 0.77 \\
\hline Average & 22 & 15 & 0.71 \\
\hline SD & 4 & 3 & 0.13 \\
\hline
\end{tabular}

Verrucomicrobiales. The relative abundance (as measured by the relative intensities of the DGGE bands) and phylogenetic affiliations of some major types (Table 2) indicate a close association with the $16 \mathrm{~S}$ rRNA genes from a sample taken $<16 \mathrm{~km}$ away (Cape May, NJ) in the GOS dataset (Rusch et al. 2007). Other ribotypes (to family or genus level) found in both datasets include Flavobacteriaceae, Rhizobium, Sphingomonas, Alteromonas, and Pseudomonas.

The 3 DGGE bands that contained SAR11 included $>1$ ribotype as determined by direct sequencing. The DGGE bands were subsequently cloned from the April and November 2007 samples, and at least 10 clones from each band were sequenced to determine their phylogenetic affiliation. While the majority were SAR11 ribotypes, all 3 bands contained up to $33 \%$ of unrelated bacterial ribotypes, especially the third type (H) (Table 2). There were 5 groups of highly related SAR11 ribotypes in the cloned samples. The nonSAR11 clones were affiliated with various proteobacterial groups (alpha, beta, gamma), and none was present more than once in the cloned samples.

\section{Ribosomal rRNAs in the Delaware coastal ocean}

To examine the bacterial members of the community containing significant levels of ribosomes, we performed RT-PCR on the 16S rRNA extracted from the same samples as the DNA used in the DGGE experiments detailed above. The ratios of identical bands present in the RNA fraction compared to the DNA frac-

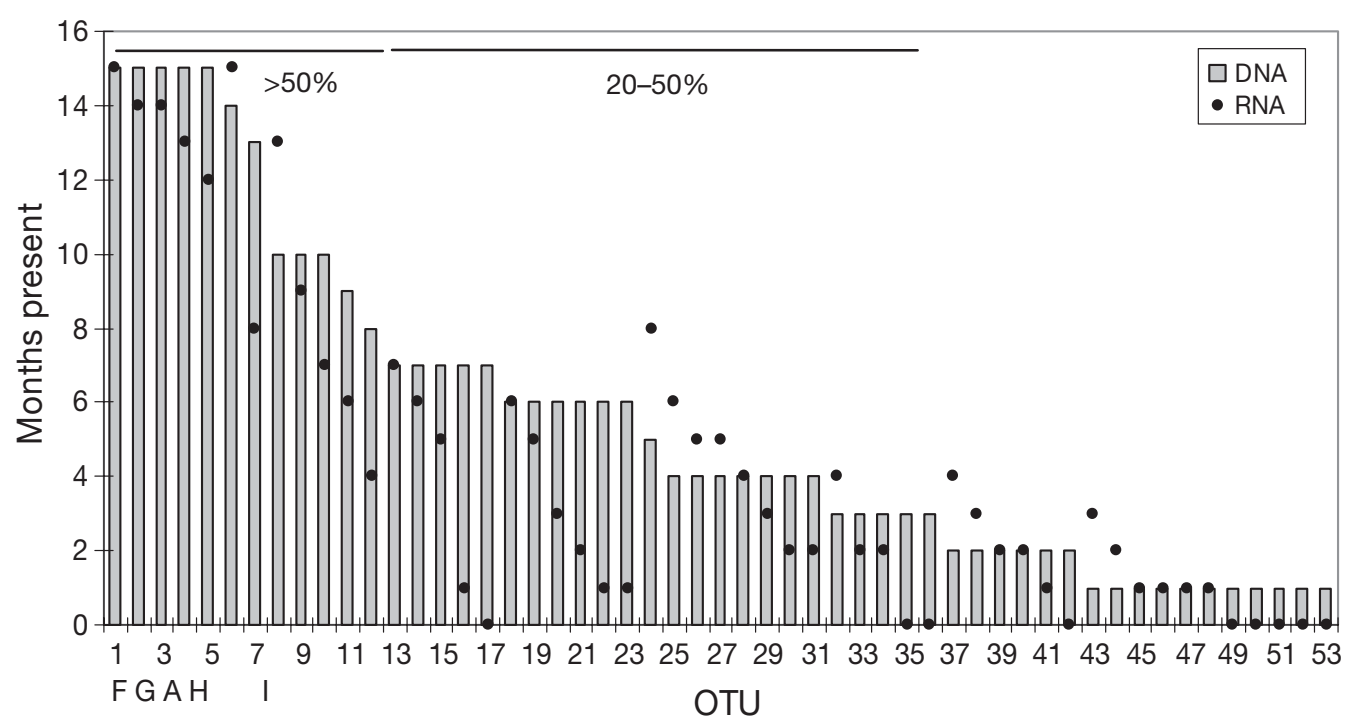

Fig. 2. Rank abundance of operational taxonomic units (OTUs) in Delaware coastal water communities over 15 mo. Nucleic acids from monthly samples were analyzed by DGGE for presence/absence of bands (ribotypes). Lines indicate the ribotypes present in the community for the indicated percentage of time. Dots indicate the identical ribotypes present in the RNA fraction for the indicated percentage of time. Letters below the $x$-axis indicate the abundant ribotypes found by DGGE (Table 2) 
tion from the same sample ranged from 0.45 to 0.90 (Table 1), with an average of $0.71 \pm 0.13$ (SD). There were no obvious patterns in the percentage of bacteria containing rRNA over seasons or between months. However, some periods had lower than average rRNA to rDNA ratios, including late summer, early fall in both years (0.45 to 0.59), and late spring in 2007 (0.59). In general, the ribotypes present in the RNA fraction were found in every month that contained the corresponding rDNA ribotype (Fig. 2). However, there were several ribotypes that were more frequently encountered in the RNA fraction compared to the DNA fraction. With 2 exceptions, these ribotypes were present $<35 \%$ of the time in the DNA fraction.

We also examined the relative intensities of RNADNA bands from abundant ribotypes (Table 2). The ratios of the relative intensities of the major ribotypes did not vary much. In general, the rRNA intensity was less than the rDNA intensity, except for one major SAR11 band (Band F). Some of the less abundant ribotypes (low rDNA intensity) appeared to be highly active (high rRNA intensity). These included, but were not limited to, representatives from the following orders: Prochlorocales, Bradyrhizobiales, Bdellovibrio, Flavobacteriales, Alteromonadales, and unclassified Alphaproteobacteria. The Flavobacteriales and un-
Table 2. Taxonomic affiliations, abundance estimates, and ratio of rRNA to rDNA based on relative intensities of selected Delaware coastal bacterioplankton identified by DGGE analysis and compared to the Cape May (CM) Global Ocean Sampling (GOS) dataset. ND: not defined

\begin{tabular}{|llccc|}
\hline Band & $\begin{array}{c}\text { Nearest } \\
\text { neighbor }\end{array}$ & $\begin{array}{c}\text { \% of } \\
\text { community } \\
\text { (SD) }\end{array}$ & $\begin{array}{c}\text { \% of 16S } \\
\text { rRA genes } \\
\text { in CM }\end{array}$ & $\begin{array}{c}\text { Ratio of rRNA } \\
\text { to rDNA } \\
\text { (SD) }\end{array}$ \\
\hline A & SAR86 & $6.9(2.8)$ & 8 & $0.5(0.4)$ \\
I & SAR116 & $4.4(3.3)$ & 3 & $0.9(0.5)$ \\
F & SAR11 & $6.0(3.5)$ & ND & $1.6(0.6)$ \\
G & SAR11 & $11.1(3.6)$ & ND & $0.8(0.4)$ \\
H & SAR11 & $11.8(4.0)$ & ND & $0.8(0.2)$ \\
Total & SAR11 & 28.9 & 32 & \\
\hline
\end{tabular}

classified Alphaproteobacteria members had numerous representatives from 16S rDNA clone libraries from coastal marine waters (data not shown). The Flavobacteriales (a Bacteroidetes subgroup) was 98 to $99 \%$ related to other estuarine bacterioplankton and to the second most abundant Bacteroidetes group in the Delaware Bay, termed the Microscilla cluster (Kirchman et al. 2003). The uncultured alphaproteobacterial group was $99 \%$ related to the marine SAR116 cluster (Giovannoni et al. 1990).

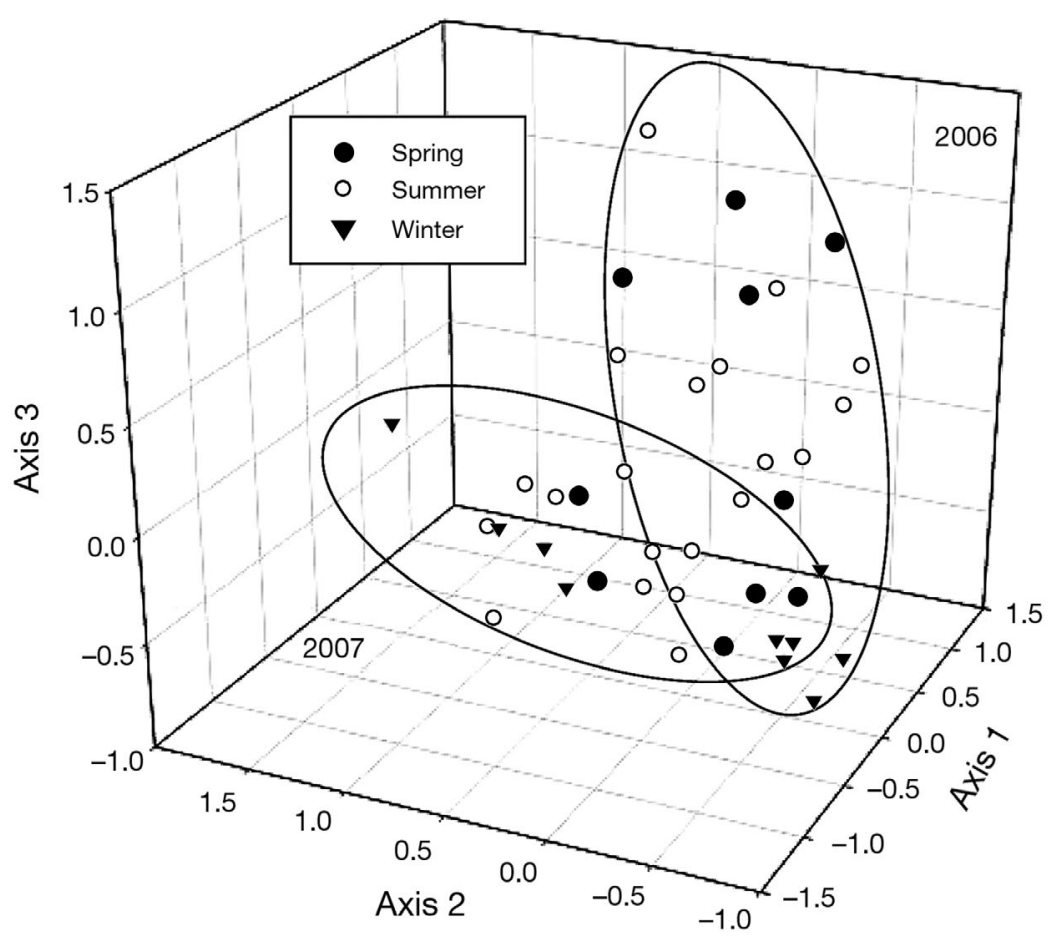

Fig. 3. Multidimensional scaling (MDS) plot of Delaware coastal water bacterial communities. Values based on the presence/absence of DGGE fragments. The 2 years are delineated by circles

\section{Relationship of bacterial community structure to environmental parameters}

Approximately $50 \%$ of the variation in bacterial community structure could be explained by 13 parameters $\left(\mathrm{NO}_{3}\right.$, $\mathrm{PO}_{4}, \mathrm{NH}_{4}, \mathrm{Si}$, leucine incorporation, temperature, salinity, chl $a$, DOC, DON, PAR, total prokaryotic abundance, and abundance of AAP bacteria) as calculated using 3 axes in CCA (McCune \& Grace 2002). The highest intraset correlations (ter Braak 1986) were total prokaryotic abundance (axis $1, \mathrm{r}=-0.66$ ), $\mathrm{PO}_{4}$ and temperature (axis 2, $\mathrm{r}=-0.60$ and -0.76 , respectively), and leucine incorporation (axis 3, r = 0.51). Similar results were found using the Mantel test. All 17 parameters explained $32 \%$ of variation $(p=0.01)$. Temperature explained the most variation in community structure $(r=0.29)$ using the subset tests.

The variation in each environmental parameter was generally greater than the variations measured in community 
Table 3.Variation among selected biotic and abiotic factors and community composition indices for Delaware coastal samples in 2006 to 2007. SD: standard deviation, CV: coefficient of variation, PAR: photosynthetically active radiation, DOC: dissolved organic carbon, DON: dissolved organic nitrogen

\begin{tabular}{|c|c|c|c|c|}
\hline \multicolumn{2}{|l|}{ Parameter } & Mean & $\mathrm{SD}$ & $\mathrm{CV}(\%)$ \\
\hline \multicolumn{5}{|l|}{ Environment } \\
\hline \multicolumn{2}{|c|}{ Leucine incorporation $\left(\mathrm{pM} \mathrm{h}^{-1}\right)$} & 132.5 & 129.2 & 98 \\
\hline \multicolumn{2}{|l|}{ Temperature $\left({ }^{\circ} \mathrm{C}\right)$} & 13.8 & 6.7 & 49 \\
\hline \multicolumn{2}{|l|}{ Salinity } & 30.4 & 1.7 & 5.7 \\
\hline \multicolumn{2}{|l|}{ Chl a $\left(\mu \mathrm{gl}^{-1}\right)$} & 6.5 & 3.8 & 58 \\
\hline \multicolumn{2}{|l|}{ Abundance $\left(10^{6}\right.$ cells ml $\left.{ }^{-1}\right)$} & 4.0 & 2.5 & 64 \\
\hline \multicolumn{2}{|l|}{ Cell size $\left(\mu \mathrm{m}^{3}\right)$} & 0.048 & 0.022 & 45 \\
\hline \multicolumn{2}{|l|}{ PAR (q $\left.\mathrm{cm}^{-2} \mathrm{~s}^{-1}\right)$} & 0.6 & 0.4 & 68 \\
\hline \multicolumn{2}{|l|}{ DOC ( $(\mu \mathrm{M} \mathrm{C})$} & 135.4 & 18.0 & 13 \\
\hline \multicolumn{2}{|l|}{$\mathrm{DON}(\mu \mathrm{M} N)$} & 11.6 & 7.0 & 61 \\
\hline \multicolumn{2}{|l|}{ Secchi (m) } & 3.0 & 1.2 & 38 \\
\hline \multicolumn{2}{|l|}{$\mathrm{NO}_{3}(\mu \mathrm{M})$} & 3.4 & 6.4 & 187 \\
\hline \multicolumn{2}{|l|}{$\mathrm{PO}_{4}(\mu \mathrm{M})$} & 0.4 & 0.3 & 97 \\
\hline \multicolumn{2}{|l|}{$\mathrm{NH}_{4}(\mu \mathrm{M})$} & 1.4 & 1.4 & 100 \\
\hline \multicolumn{2}{|l|}{$\mathrm{Si}(\mu \mathrm{M})$} & 8.5 & 6.1 & 72 \\
\hline \multicolumn{5}{|l|}{ Community structure } \\
\hline \multirow[t]{2}{*}{ Number of DGGE bands } & DNA & 22 & 4.1 & 19 \\
\hline & RNA & 15 & 3.0 & 20 \\
\hline \multirow[t]{2}{*}{ DGGE similarity } & DNA & 0.57 & 0.10 & 18 \\
\hline & RNA & 0.52 & 0.12 & 23 \\
\hline \multirow{3}{*}{ rDNA abundance } & SAR11 & 91.3 & 45.4 & 50 \\
\hline & Cyto & 7.2 & 3.7 & 51 \\
\hline & SAR116 & 14.3 & 6.8 & 48 \\
\hline \multirow[t]{3}{*}{ rRNA:rDNA ratios } & SAR11 & 143 & 75.6 & 53 \\
\hline & Cyto & 478 & 309 & 65 \\
\hline & SAR116 & 25.7 & 13.9 & 54 \\
\hline
\end{tabular}

structure changes over the 2 yr period (Table 3 ). The coefficient of variation (CV) was $>38 \%$ for all biotic and abiotic factors measured, except for salinity and DOC. The variation in community composition between samples as measured by the number of DGGE bands or by the similarity of band presence and absence ranged from 18 to $23 \%$, with the higher variations occurring in the RNA fractions.

CCA was performed on 5 of the most significant of the environmental factors (temperature, phosphate concentration, leucine incorporation, PAR, and DOC) with the OTU presence/absence matrices of both the rDNA and rRNA communities by DGGE analyses (Fig. 4). The 5 environmental parameters explained about $40 \%$ of the variance in the 3 canonical axes in both community types. Two-dimensional CCA plots indicated that the summer samples from 2006 (rRNA and rDNA samples) were located closest to 4 of the environmental parameters (temperature, phosphate concentration, leucine incorporation, PAR) and were negatively correlated with DOC levels. The rRNA communities from winter/spring 2007 samples covar- ied more with DOC levels than the rDNA communities from the same period and were negatively correlated with the other 4 parameters. The rDNA communities from October 2006 and July 2007 samples covaried more with the DOC levels than the rRNA communities from winter/spring 2007.

\section{rRNA and rRNA gene abundance in selected bacterioplankton}

Three members of the community were chosen for quantification of their 16S rRNA and rRNA gene copies via qPCR and qRT-PCR: SAR11, because of the high abundance of this group in our samples as estimated by DGGE, and a SAR116-like and a Cytophaga subgroup because of differential presence and activity as indicated by DGGE analysis. The rDNA levels of the 3
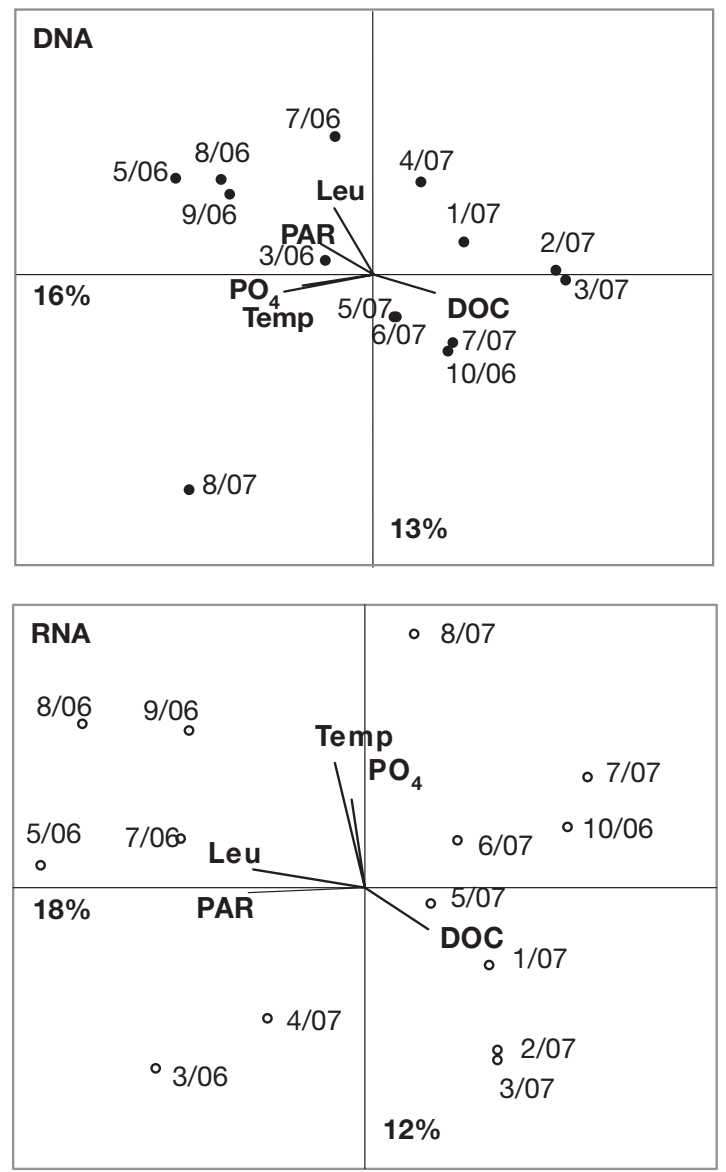

Fig. 4. Ordination diagram from canonical correspondence analysis of 16S rRNA and rDNA OTUs compared to paired environmental data. Temp: temperature, $\mathrm{PO}_{4}$ : phosphate concentration, Leu: leucine incorporation, PAR: photosynthetically active radiation, DOC: dissolved organic carbon concentration. Numbers are mm/yy. \% values are variation explained by the corresponding axis 


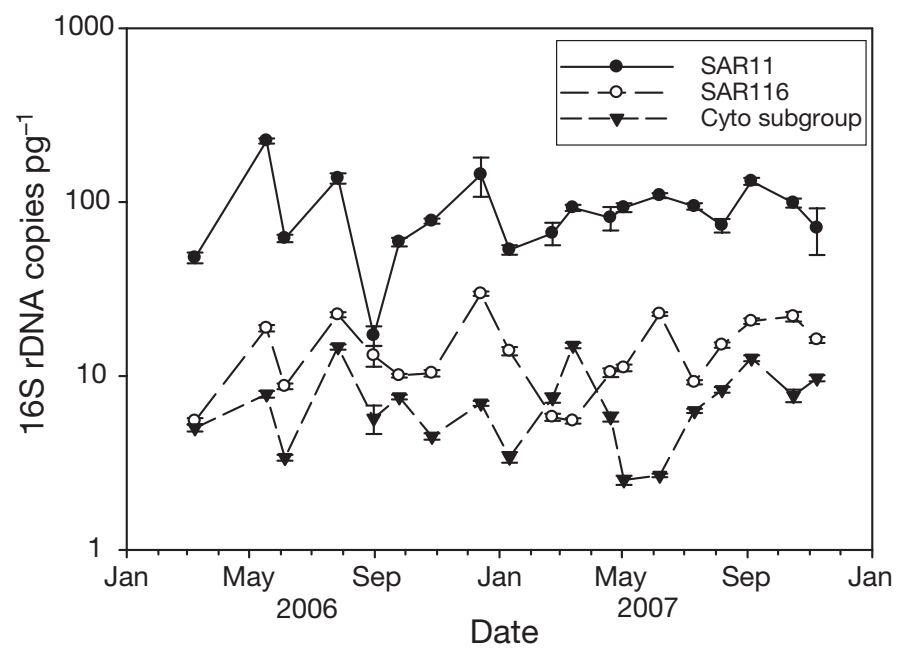

Fig. 5. rDNA copies of 3 bacterial groups over time. Copies were normalized to pg of total DNA. Cyto: Cytophaga. Data are mean $\pm \mathrm{SE}$

groups did not vary substantially (usually 5- to 6-fold) in 2006-2007 (Fig. 5). The SAR11 clade was, on average, approximately 10 -fold more abundant than either of the other 2 groups. The average 16S rDNA copies $\mathrm{pg}^{-1}$ of DNA were 91, 7, and 14 for the SAR11 clade, the Cytophaga subgroup, and the SAR116-like group, respectively (Fig. 5). When measured by CARD-FISH, the SAR11 clade made up $38 \pm 12 \%$ (mean \pm SD) of the total DAPI-stained cells and $50 \pm 13 \%$ of the probepositive bacterial cells. Bacteria (EUB-338 positive cells) made up $76 \pm 8 \%$ of all prokaryotes.

The rRNA to rDNA ratios within a single group varied greatly during 2006-2007 (Fig. 6). Within the SAR11 clade, the ratios ranged from 17 to 294, with an average of $143 \pm 76$ (mean \pm SD). There was no obvious seasonality in these ratios, but 2 months of the first winter (November, December 2006) had low rRNA to rDNA ratios $(<100)$, and the ratios were generally higher (>200) in both springs (March 2006, February 2007) and early summer (June 2006; April to May 2007). The peaks of abundance and ratios of rRNA to rDNA of the SAR11 members were offset by 1 mo in 2006 (Figs. 5, 6). This was not the case in 2007.

The Cytophaga subgroup had higher ratios of rRNA to rDNA than did the SAR11 clade, ranging from 76 to 1028 (Fig. 6), with an average of $478 \pm 309$ (mean \pm $\mathrm{SD})$. Seven of the 19 mo had values $>600$. With 2 exceptions, the ratios were higher in the spring and summer $(>300)$ and then declined in early winter in both 2006 and $2007(<300)$. However, if corrected to estimated copies of the 16S rRNA gene per genome (SAR11 1 copy, Giovannoni et al. 2005b; Cytophaga \% copies, see 'Materials and methods') instead of absolute 16S rRNA gene numbers, the ratios of rRNA to rDNA were similar between the SAR11 clade and the Cytophaga subgroup, with ranges of 17 to 294 and 15 to 206 and averages of 143 and 96 for the 2 groups, respectively. The ratio of rRNA to rDNA in the SAR116-like group was much lower than either of the other 2 groups (Fig. 6). The ratio ranged from 8 to 68, with an average of $26 \pm 14$ (mean $\pm \mathrm{SD}$ ). The ratios were highest in the spring and in late summer of both years $(>20)$.

\section{Relationship of bacterial rRNA and rDNA gene copies to environmental parameters}

SAR11 abundance was significantly correlated with PAR as measured by both the relative intensity of DGGE bands ( $\mathrm{r}=0.59, \mathrm{p}<0.05, \mathrm{n}=17)$ and 16S rRNA gene copy number $(\mathrm{r}=0.68, \mathrm{p}<0.01, \mathrm{n}=20)$. In contrast, there was no correlation between PAR and the abundance of the other 2 groups. The DGGE and qPCR abundance estimates of the SAR11 clade were

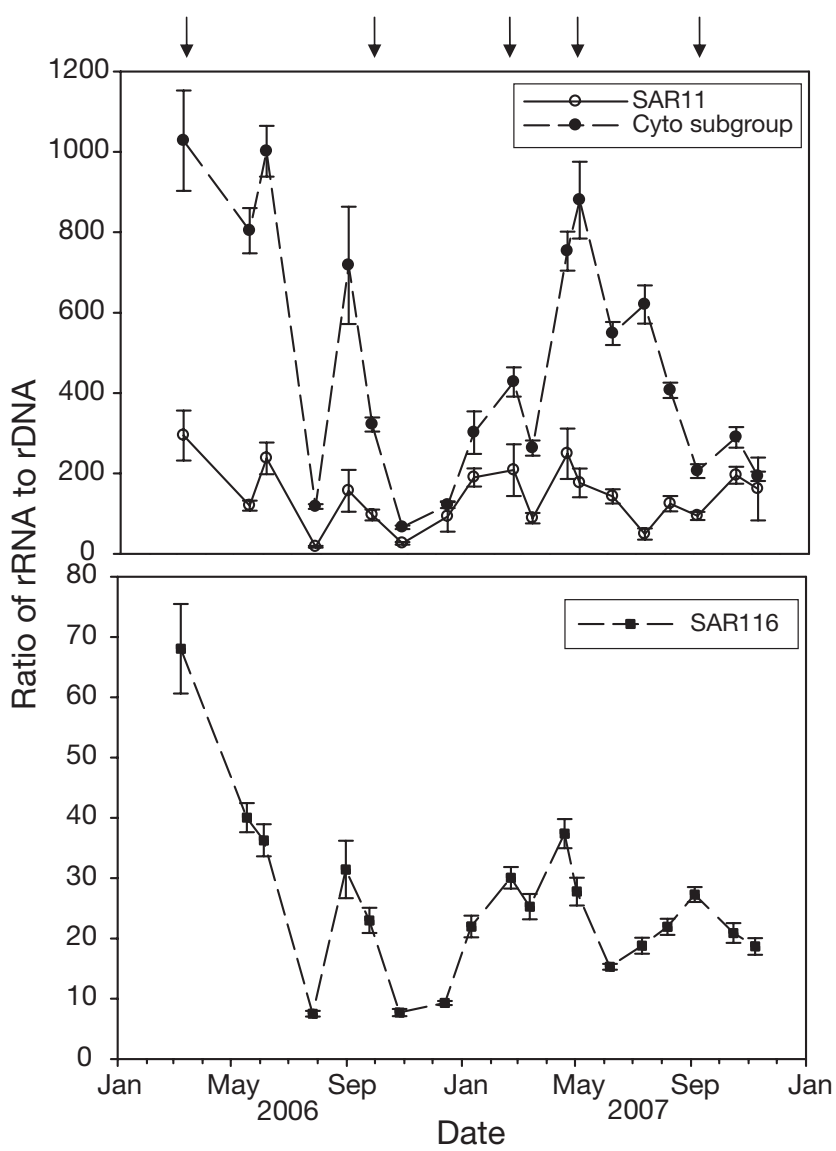

Fig. 6. rRNA copies compared to rDNA copies of 3 bacterial groups over time. Copies were first normalized to $\mathrm{pg}$ of total DNA or RNA. Note differences in scale between the 2 panels. Arrows indicate peak chl a concentrations. Cyto: Cytophaga. Data are mean $\pm \mathrm{SE}$ 
positively correlated with each other $(\mathrm{r}=0.58, \mathrm{p}<0.05$, $\mathrm{n}=17$, but not with CARD-FISH $(\mathrm{r}=0.42, \mathrm{p}>0.05, \mathrm{n}=$ 10). The abundance of this group as measured by CARD-FISH was significantly correlated with the ratio of SAR11-specific rRNA:rDNA ( $\mathrm{r}=0.67, \mathrm{p}<0.05, \mathrm{n}=$ 10). The CVs in the abundance of each group over time ranged from 48 to $51 \%$ (Table 3 ). This variation was higher than total community structure variation as measured by DGGE and was more comparable to that of many environmental parameters.

There were significant correlations between the rRNA:rDNA ratios of all bacterial groups, with $r$ values above 0.67 ( $\mathrm{p}<0.01, \mathrm{n}=20)$. The highest correlation was between the Cytophaga subgroup and the SAR116-like group ( $\mathrm{r}=0.79, \mathrm{p}<0.001, \mathrm{n}=20$ ). However, only some of the rRNA:rDNA ratios or abundances (as measured by qPCR) correlated with environmental parameters. The Cytophaga subgroup rRNA:rDNA ratios were significantly but negatively correlated with $\mathrm{NO}_{3}(\mathrm{r}=-0.51, \mathrm{p}<0.05, \mathrm{n}=15)$ and $\mathrm{PO}_{4}(\mathrm{r}=-0.52, \mathrm{p}<0.05, \mathrm{n}=15)$. The SAR116-like rRNA:rDNA ratios were positively correlated with chl $a(\mathrm{r}=0.51, \mathrm{p}<0.05, \mathrm{n}=19)$. However, the abundance of the SAR116-like group was negatively correlated with chl a $(\mathrm{r}=-0.52, \mathrm{p}<0.05, \mathrm{n}=19)$. The CVs of the rRNA:rDNA ratios were slightly higher than the CVs of the corresponding ribotype group abundance, with values ranging from 53 to $65 \%$ (Table 3). Again, these were more similar to the variation observed with the environmental factors over time than to the variations in overall community similarity.

\section{DISCUSSION}

Delaware coastal waters are eutrophic and seasonally dynamic, with only somewhat predictable seasonal environmental conditions. The study site is under the influence of the Delaware Bay, with lower than typical coastal salinity and highly variable factors, such as inorganic nutrient concentrations. The generally high DOC concentrations and bacterial abundances throughout the present study also indicate eutrophic estuarine and terrestrial inputs to this environment. The microbial community structure and growth in this coastal ecosystem are most likely influenced not only by top-down pressures such as grazing and lysis (Gasol et al. 2002, Yokokawa \& Nagata 2005) not measured in the present study, but also by fluctuating bottom-up factors.

Although rRNA levels compared to rDNA levels have been used as a proxy for potential bacterial growth and activity in the past (Ka et al. 2001, Schafer et al. 2001, Troussellier et al. 2002, Gentile et al. 2006, Lami et al. 2009), this is the first study to quantitatively assess temporal changes in individual bacterial 16S rRNA and rRNA genes. rRNA levels generally follow bacterial growth, with increased rRNA to rDNA ratios during the exponential phase (Fegatella et al. 1998, Kerkhof \& Kemp 1999, Deutscher 2006). rRNA levels decline during the starvation phase of growth (Kerkhof \& Kemp 1999, Deutscher 2006). We did find that quantitative PCR was a much better tool to assess individual ribotype rRNA and rDNA levels and ratios than the more qualitative DGGE. Additionally, to avoid problems associated with amplifying plastids from eukaryotes with general DGGE primers, we focused on the free-living fractions and therefore may have missed certain groups commonly found associated with particles, such as Roseobacter spp., in the DGGE analyses (Buchan et al. 2005).

While the composition of the communities did not vary much over time, we found that the abundance of individual bacterial groups changed more, with the greatest variability observed in the levels of ribosomes when normalized to genome content (rRNA genes). The ribosome to rRNA gene contents of the 3 groups were positively correlated with each other, which suggests that their activities are influenced by similar factors. In support of this, environmental factors explained approximately $50 \%$ of the variation in the structure of the bacterial communities. Perhaps more interesting is that none of these indices varied as much as most of the environmental parameters, suggesting that overall community structure is relatively stable in the face of large shifts in the environment.

There was no seasonal pattern in the bacterial community structure or in the abundance and potential activity of the SAR11 clade, Cytophaga and SAR116like subgroups at our coastal Mid-Atlantic site. In a recent long-term seasonal survey of the bacterioplankton community structure of a coastal California Microbial Observatory, Fuhrman et al. (2006) identified patterns in OTU presence and relative abundance when 171 unique OTUs (ribotypes) were divided into smaller groups. While there were no patterns in the community structure of the winter or spring surface bacterial communities in a Bermuda Atlantic time-series (BATS) study, the summer samples tended to cluster together, suggesting that similar communities exist in highlyoligotrophic conditions in the Sargasso Sea (Morris et al. 2005). Like other single-year seasonal studies of bacterioplankton from coastal environments, the clusters we observed grouped according to season (Schauer et al. 2003, Reinthaler et al. 2005, Mary et al. 2006, Celussi \& Cataletto 2007, Alonso-Sáez et al. 2008). However, the samples from identical seasons over the 2 yr period did not cluster together, most likely due to the shifts in the minor members of the community. 
Overall bacterial community activity as assayed by rRNA and rDNA DGGE bands was similar to what others have seen, around $70 \%$ (Troussellier et al. 2002, Lami et al. 2009). This value is similar to the total CARD-FISH positive bacterial cells of $76 \%$. We did find several minor ribotypes that were much more abundant in the RNA fractions, including members of the alpha, beta, and gamma subdivisions of the Proteobacteria and the Bacteroidetes, suggesting that they were more active at certain times during the study period. These types of active bacteria are similar to what we have seen at a broader phylogenetic level by the use of Micro-FISH in the Delaware Bay (Cottrell \& Kirchman 2003, 2004).

The abundance of the SAR11 clade was significantly correlated with PAR, agreeing with our previous work demonstrating the overwhelming presence of the light-harvesting gene proteorhodopsin in this group and the correlation of the SAR11 proteorhodopsin gene to light intensity (Campbell et al. 2008). However, despite the large temporal variation in the SAR11 rRNA to rDNA ratios, we did not see any significant correlations of rRNA abundance with environmental parameters, including PAR. There was no significant effect of light on the growth of Pelagibacter ubique, even though it contains proteorhodopsin (Giovannoni et al. 2005a). These combined results point to a complex system, where light influences the abundance of the SAR11 clade, but other factors are probably more important in controlling its activity. The SAR11 clade is very diverse and is made up of several subgroups (Field et al. 1997, Morris et al. 2005, Rusch et al. 2007, Carlson et al. 2009). Each individual SAR11 member is probably influenced by slightly different environmental factors, and would be most active under different conditions (Field et al. 1997, Morris et al. 2005, Carlson et al. 2009).

The SAR11 clade has been hypothesized to be slowgrowing, K-selected, and not very active (Rappé et al. 2002, Giovannoni et al. 2005b). However, we found the SAR11 clade at the coastal site to be not only abundant but to contain a high and temporally variable specific ribosome content. Although the numbers of ribosomes per 16S rDNA copies in the SAR11 clade were less than the numbers we observed in the Cytophaga subgroup, when normalized to estimated numbers of $16 \mathrm{~S}$ rRNA genes in the 2 groups, they were nearly the same. This suggests that the relative activities of these 2 groups may be similar. Our study supports the hypothesis that members of the SAR11 clade found in coastal eutrophic waters of Delaware are as active as other bacteria in the ocean (Malmstrom et al. 2004, 2005, Longnecker et al. 2005). Additionally, variation in 16S rRNA to rDNA levels agrees with the seasonality of the SAR11 clade as measured by FISH and rRNA hybridizations (Morris et al. 2002, 2005, Alonso-Sáez et al. 2007). Clearly, further experiments need to be performed to understand the dynamics and activities of individual SAR11 subgroups, especially in eutrophic environments.

The Cytophaga subgroup (Microscilla cluster) was first observed in 16S rRNA gene clone libraries from a wide variety of estuarine and coastal waters (Kirchman et al. 2003, Acinas et al. 2004, Lau \& Armbrust 2006, Pommier et al. 2007). This ribotype group was also found in the GOS shotgun library dataset, in both oligotrophic and eutrophic environments (Rusch et al. 2007), including the Sargasso Sea (Pommier et al. 2007). We only saw this group occasionally in the DGGE analysis, so we were surprised to find that the abundance of this population was relatively stable over the 2 yr by 16S rDNA qPCR analysis. This shows the limitations of using DGGE, especially as a tool to follow the less abundant members of the community.

Perhaps more interesting is the activity of the Cytophaga subgroup. These bacteria were shown to be active in the eutrophic Inland Sea of Japan by combined bromodeoxyuridine-incorporation and DGGE assays (Hamasaki et al. 2007). In the present study, the ratios of rRNA:rDNA in the Cytophaga subgroup as estimated by qPCR varied greatly, suggesting that this group has variable relative activity. We observed a few significant relationships with environmental parameters, especially a significant negative correlation with nitrate. Although there was no correlation with chl $a$, the peaks in rRNA:rDNA mostly followed the peaks in chl a concentrations. These data, combined with the negative correlation with nitrate, suggest that this group may be active after phytoplankton blooms, during subsequent increases in dissolved organic matter. Other studies have also demonstrated the link between the abundance of the Bacteroidetes phylum and phytoplankton blooms (Pinhassi et al. 2004, Fandino et al. 2005, Bauer et al. 2006). Studies with members of both Cytophaga and Roseobacter suggest that specific bacteria within these same groups may be responsible for carbon processing at bloom peaks and declines (Fandino et al. 2005, West et al. 2008).

Unlike the SAR11 clade and Cytophaga subgroup, we did not see a large variation in the ratio of $16 \mathrm{~S}$ rRNA to rDNA copies of the SAR116-like group, either by DGGE or qPCR-based methods. SAR116 is a cosmopolitan, but not abundant, member of the Alphaproteobacteria and is found in open ocean environments as well as in coastal areas (Giovannoni et al. 1990, Suzuki et al. 1997, 2004, Pommier et al. 2007). Our estimates of SAR116-like bacterial abundance in coastal Delaware waters agree with these observations. The rRNA:rDNA ratios of the SAR116-like group also correlated with chl $a$, suggesting this bacterial group is 
most active when phytoplankton are most abundant. However, rRNA to rDNA ratios were low, suggesting this group may not be very active in these eutrophic marine waters. In contrast, the SAR116-like group is one of the most abundant ribotypes in the Sargasso Sea during the summer months, under highly oligotrophic conditions (Morris et al. 2005).

\section{CONCLUSION}

We examined the temporal changes in bacterial community structure and potential activity in a complex coastal site under the continual influence of strong physical factors. The bacterial community structure varied little compared to the variation observed in environmental factors. However, the abundance and potential activity of individual ribotypes in these coastal waters varied more over time, of which approximately $50 \%$ could be explained by a suite of environmental factors. Our data suggest that the activity of individual ribotype groups, including SAR11, is highly variable but can be assessed by measuring rRNA: rDNA ratios. While FISH or CARD-FISH is useful for broad phylogenetic groups, or for members that make up a significant proportion of the community, the method described here is useful for specific ribotypes or those present as minor members of the community. The present study highlights the need for an in-depth examination of the activity of both broad phylogenetic groups and individual ribotypes in marine systems in order to understand their contributions to important biogeochemical cycles.

Acknowledgements. This work was supported by grants to D.L.K. (NSF MCB-0453993) and to B.J.C. and D.L.K (NSF OCE-0825468). We thank M. Cottrell and V. Michelou for help with sampling and data analysis.

\section{LITERATURE CITED}

Acinas SG, Klepac-Ceraj V, Hunt DE, Pharino C, Ceraj I, Distel DL, Polz MF (2004) Fine-scale phylogenetic architecture of a complex bacterial community. Nature 430:551-554

Alonso-Sáez L, Gasol JM (2007) Seasonal variations in the contributions of different bacterial groups to the uptake of low-molecular-weight compounds in northwestern Mediterranean coastal waters. Appl Environ Microbiol 73: 3528-3535

Alonso-Sáez L, Balague V, Sa EL, Sanchez O and others (2007) Seasonality in bacterial diversity in north-west Mediterranean coastal waters: assessment through clone libraries, fingerprinting and FISH. FEMS Microbiol Ecol 60:98-112

- Alonso-Sáez L, Vazquez-Dominguez E, Cardelus C, Pinhassi $\mathrm{J}$ and others (2008) Factors controlling the year-round variability in carbon flux through bacteria in a coastal marine system. Ecosystems 11:397-409
Amann RI, Binder BJ, Olson RJ, Chisholm SW, Devereux R, Stahl DA (1990) Combination of 16S rDNA-targeted oligonucleotide probes with flow cytometry for analyzing mixed microbial populations. Appl Environ Microbiol 56:1919-1925

Bauer M, Kube M, Teeling H, Richter M and others (2006) Whole genome analysis of the marine Bacteroidetes 'Gramella forsetii' reveals adaptations to degradation of polymeric organic matter. Environ Microbiol 8: 2201-2213

> Buchan A, González JM, Moran MA (2005) Overview of the marine Roseobacter lineage. Appl Environ Microbiol 71: 5665-5677

> Campbell BJ, Cary SC (2001) Characterization of a novel spirochete associated with the hydrothermal vent polychaete annelid, Alvinella pompejana. Appl Environ Microbiol 67:110-117

Campbell BJ, Waidner LA, Cottrell MT, Kirchman DL (2008) Abundant proteorhodopsin genes in the North Atlantic Ocean. Environ Microbiol 10:99-109

Carlson CA, Morris R, Parsons R, Treusch AH, Giovannoni SJ, Vergin K (2009) Seasonal dynamics of SAR11 populations in the euphotic and mesopelagic zones of the northwestern Sargasso Sea. ISME J 3:283-295

Castle DM, Montgomery MT, Kirchman DL (2006) Effects of naphthalene on microbial community composition in the Delaware estuary. FEMS Microbiol Ecol 56:55-63

Celussi M, Cataletto B (2007) Annual dynamics of bacterioplankton assemblages in the Gulf of Trieste (Northern Adriatic Sea). Gene 406:113-123

Cottrell MT, Kirchman DL (2000) Natural assemblages of marine Proteobacteria and members of the CytophagaFlavobacter cluster consuming low- and high- molecularweight dissolved organic matter. Appl Environ Microbiol 66:1692-1697

Cottrell MT, Kirchman DL (2003) Contribution of major bacterial groups to bacterial biomass production (thymidine and leucine incorporation) in the Delaware Estuary. Limnol Oceanogr 48:168-178

Cottrell MT, Kirchman DL (2004) Single-cell analysis of bacterial growth, cell size, and community structure in the Delaware estuary. Aquat Microb Ecol 34:139-149

Cottrell MT, Mannino A, Kirchman DL (2006) Aerobic anoxygenic phototrophic bacteria in the Mid-Atlantic Bight and the North Pacific Gyre. Appl Environ Microbiol 72: 557-564

del Giorgio PA, Gasol JM (2008) Physiological structure and single-cell activity in marine bacterioplankton. In: Kirchman DL (ed) Microbial ecology of the oceans. WileyBlackwell, Hoboken, NJ, p 243-298

Dempster EL, Pryor KV, Francis D, Young JE, Rogers HJ (1999) Rapid DNA extraction from ferns for PCR-based analyses. Biotechniques 27:66-68

DeSantis TZ, Hugenholtz P, Keller K, Brodie EL and others (2006a) NAST: a multiple sequence alignment server for comparative analysis of 16S rRNA genes. Nucleic Acids Res 34:W394-W399

DeSantis TZ, Hugenholtz P, Larsen N, Rojas M and others (2006b) Greengenes, a chimera-checked 16S rRNA gene database and workbench compatible with ARB. Appl Environ Microbiol 72:5069-5072

> Deutscher MP (2006) Degradation of RNA in bacteria: comparison of mRNA and stable RNA. Nucleic Acids Res 34: 659-666

Ducklow H (2000) Bacterial production and biomass in the oceans. In: Kirchman DL (ed) Microbial ecology of the oceans. John Wiley \& Sons, New York, p 85-120 
Fandino LB, Riemann L, Steward GF, Azam F (2005) Population dynamics of Cytophaga-Flavobacteria during marine phytoplankton blooms analyzed by real-time quantitative PCR. Aquat Microb Ecol 40:251-257

> Fegatella F, Lim J, Kjelleberg S, Cavicchioli R (1998) Implications of rRNA operon copy number and ribosome content in the marine oligotrophic ultramicrobacterium Sphingomonas sp. strain RB2256. Appl Environ Microbiol 64: 4433-4438

Field KG, Gordon D, Wright T, Rappé M, Urbach E, Vergin K, Giovannoni SJ (1997) Diversity and depth-specific distribution of SAR11 cluster rRNA genes from marine planktonic bacteria. Appl Environ Microbiol 63:63-70

- Fuhrman JA, Hewson I, Schwalbach MS, Steele JA, Brown MV, Naeem S (2006) Annually reoccurring bacterial communities are predictable from ocean conditions. Proc Natl Acad Sci USA 103:13104-13109

Gasol JM, Pedrós-Alio C, Vaqué D (2002) Regulation of bacterial assemblages in oligotrophic plankton systems: results from experimental and empirical approaches. Antonie Leeuwenhoek 81:435-452

Gentile G, Giuliano L, D'Auria G, Smedile F, Azzaro M, De Domenico M, Yakimov MM (2006) Study of bacterial communities in Antarctic coastal waters by a combination of 16S rRNA and 16S rDNA sequencing. Environ Microbiol 8:2150-2161

Ghiglione JF, Larcher M, Lebaron P (2005) Spatial and temporal scales of variation in bacterioplankton community structure in the NW Mediterranean Sea. Aquat Microb Ecol 40:229-240

Giovannoni SJ, Stingl U (2005) Molecular diversity and ecology of microbial plankton. Nature 437:343-348

Giovannoni SJ, Britschgi TB, Moyer CL, Field KG (1990) Genetic diversity in Sargasso Sea bacterioplankton. Nature 345:60-63

Giovannoni SJ, Bibbs L, Cho JC, Stapels MD and others (2005a) Proteorhodopsin in the ubiquitous marine bacterium SAR11. Nature 438:82-85

- Giovannoni SJ, Tripp HJ, Givan S, Podar M and others (2005b) Genome streamlining in a cosmopolitan oceanic bacterium. Science 309:1242-1245

Hamasaki K, Taniguchi A, Tada Y, Long RA, Azam F (2007) Actively growing bacteria in the Inland Sea of Japan, identified by combined bromodeoxyuridine immunocapture and denaturing gradient gel electrophoresis. Appl Environ Microbiol 73:2787-2798

Hammer Ø, Harper DAT, Ryan PD (2001) PAST: paleontological statistics software package for education and data analysis. Palaeontol Electronica 4:4

Ka JO, Yu Z, Mohn WW (2001) Monitoring the size and metabolic activity of the bacterial community during biostimulation of fuel-contaminated soil using competitive PCR and RT-PCR. Microb Ecol 42:267-273

Karner M, Fuhrman JA (1997) Determination of active marine bacterioplankton: a comparison of universal 16S rRNA probes, autoradiography, and nucleoid staining. Appl Environ Microbiol 63:1208-1213

Kerkhof L, Kemp P (1999) Small ribosomal RNA content in marine Proteobacteria during non-steady-state growth. FEMS Microbiol Ecol 30:253-260

Kirchman DL, Yu LY, Fuchs BM, Amann R (2001) Structure of bacterial communities in aquatic systems as revealed by filter PCR. Aquat Microb Ecol 26:13-22

- Kirchman DL, Yu LY, Cottrell MT (2003) Diversity and abundance of uncultured Cytophaga-like bacteria in the Delaware Estuary. Appl Environ Microbiol 69: 6587-6596
Kirchman DL, Dittel AI, Malmstrom RR, Cottrell MT (2005) Biogeography of major bacterial groups in the Delaware estuary. Limnol Oceanogr 50:1697-1706

Lami R, Ghiglione JF, Desdevises Y, West N, Lebaron P (2009) Annual patterns of presence and activity of marine bacterial monitored by 16S rDNA-16S rRNA fingerprints in the coastal NW Mediterranean Sea. Aquat Microb Ecol 54: 199-210

> Lau WWY, Armbrust EV (2006) Detection of glycolate oxidase gene glcD diversity among cultured and environmental marine bacteria. Environ Microbiol 8:1688-1702

Legendre P, Legendre L (1998) Numerical ecology, 2nd English edn. Elsevier, Amsterdam

> Longnecker K, Sherr BF, Sherr EB (2005) Activity and phylogenetic diversity of bacterial cells with high and low nucleic acid content and electron transport system activity in an upwelling ecosystem. Appl Environ Microbiol 71: $7737-7749$

Makarenkov V, Legendre P (2002) Nonlinear redundancy analysis and canonical correspondence analysis based on polynomial regression. Ecology 83:1146-1161

Malmstrom RR, Kiene RP, Cottrell MT, Kirchman DL (2004) Contribution of SAR11 bacteria to dissolved dimethylsulfoniopropionate and amino acid uptake in the North Atlantic Ocean. Appl Environ Microbiol 70:4129-4135

Malmstrom RR, Cottrell MT, Elifantz H, Kirchman DL (2005) Biomass production and assimilation of dissolved organic matter by SAR11 bacteria in the Northwest Atlantic Ocean. Appl Environ Microbiol 71:2979-2986

- Mary I, Cummings DG, Biegala IC, Burkill PH, Archer SD, Zubkov MV (2006) Seasonal dynamics of bacterioplankton community structure at a coastal station in the western English Channel. Aquat Microb Ecol 42:119-126

McCune B, Grace JB (with Urban DL) (2002) PC-ORD. Analysis of ecological communities. MJM Software Design, Gleneden Beach, OR

- Michelou VK, Cottrell MT, Kirchman DL (2007) Light-stimulated bacterial production and amino acid assimilation by cyanobacteria and other microbes in the North Atlantic Ocean. Appl Environ Microbiol 73:5539-5546

> Morris RM, Rappé MS, Connon SA, Vergin KL, Siebold WA, Carlson CA, Giovannoni SJ (2002) SAR11 clade dominates ocean surface bacterioplankton communities. Nature 420: 806-810

Morris RM, Vergin KL, Cho JC, Rappé MS, Carlson CA, Giovannoni SJ (2005) Temporal and spatial response of bacterioplankton lineages to annual convective overturn at the Bermuda Atlantic Time-series Study site. Limnol Oceanogr 50:1687-1696

Pernthaler A, Pernthaler J, Amann R (2002a) Fluorescence in situ hybridization and catalyzed reporter deposition for the identification of marine bacteria. Appl Environ Microbiol 68:3094-3101

Pernthaler A, Pernthaler J, Schattenhofer M, Amann R (2002b) Identification of DNA-synthesizing bacterial cells in coastal North Sea plankton. Appl Environ Microbiol 68: $5728-5736$

Pinhassi J, Sala MM, Havskum H, Peters F, Guadayol O, Malits A, Marrase CL (2004) Changes in bacterioplankton composition under different phytoplankton regimens. Appl Environ Microbiol 70:6753-6766

- Pommier T, Canback B, Riemann L, Bostrom KH and others (2007) Global patterns of diversity and community structure in marine bacterioplankton. Mol Ecol 16:867-880

Preen KE, Kirchman DL (2004) Microbial respiration and production in the Delaware Estuary. Aquat Microb Ecol 37: 109-119 
Rappé MS, Vergin K, Giovannoni SJ (2000) Phylogenetic comparisons of a coastal bacterioplankton community with its counterparts in open ocean and freshwater systems. FEMS Microbiol Ecol 33:219-232

Rappé MS, Connon SA, Vergin KL, Giovannoni SJ (2002) Cultivation of the ubiquitous SAR11 marine bacterioplankton clade. Nature 418:630-633

Reinthaler T, Winter C, Herndl GJ (2005) Relationship between bacterioplankton richness, respiration, and production in the southern North Sea. Appl Environ Microbiol 71:2260-2266

Rusch DB, Halpern AL, Sutton G, Heidelberg KB and others (2007) The Sorcerer II Global Ocean Sampling Expedition: Northwest Atlantic through Eastern Tropical Pacific. PLoS Biol 5:e77

Schafer H, Bernard L, Courties C, Lebaron P and others (2001) Microbial community dynamics in Mediterranean nutrient-enriched seawater mesocosms: changes in the genetic diversity of bacterial populations. FEMS Microbiol Ecol 34:243-253

Schauer M, Balague V, Pedros-Alio C, Massana R (2003) Seasonal changes in the taxonomic composition of bacterioplankton in a coastal oligotrophic system. Aquat Microb Ecol 31:163-174

Stingl U, Tripp HJ, Giovannoni SJ (2007) Improvements of high-throughput culturing yielded novel SAR11 strains and other abundant marine bacteria from the Oregon coast and the Bermuda Atlantic Time Series study site. ISME J 1:361-371

Straza TRA, Cottrell MT, Ducklow HW, Kirchman DL (2009) Geographic and phylogenetic variation in bacterial biovolume using protein and nucleic acid staining. Appl Environ Microbiol 75:4028-4034

Suzuki MT, Rappé MS, Haimberger ZW, Winfield H, Adair N, Strobel J, Giovannoni SJ (1997) Bacterial diversity among

Editorial responsibility: Jed Fuhrman,

Los Angeles, California, USA small-subunit rRNA gene clones and cellular isolates from the same seawater sample. Appl Environ Microbiol 63:983-989

Suzuki MT, Preston CM, Chavez FP, DeLong EF (2001) Quantitative mapping of bacterioplankton populations in seawater: field tests across an upwelling plume in Monterey Bay. Aquat Microb Ecol 24:117-127

Suzuki MT, Preston CM, Beja O, de la Torre JR, Steward GF, DeLong EF (2004) Phylogenetic screening of ribosomal RNA gene-containing clones in bacterial artificial chromosome (BAC) libraries from different depths in Monterey Bay. Microb Ecol 48:473-488

Teira E, Gasol JM, Aranguren-Gassis M, Fernandez A, Gonzalez J, Lekunberri I, Alvarez-Salgado XA (2008) Linkages between bacterioplankton community composition, heterotrophic carbon cycling and environmental conditions in a highly dynamic coastal ecosystem. Environ Microbiol 10:906-917

$>$ ter Braak CJF (1986) Canonical correspondence analysis - a new eigenvector technique for multivariate direct gradient analysis. Ecology 67:1167-1179

Troussellier M, Schafer H, Batailler N, Bernard L and others (2002) Bacterial activity and genetic richness along an estuarine gradient (Rhone River plume, France). Aquat Microb Ecol 28:13-24

- West NJ, Obernosterer I, Zemb O, Lebaron P (2008) Major differences of bacterial diversity and activity inside and outside of a natural iron-fertilized phytoplankton bloom in the Southern Ocean. Environ Microbiol 10:738-756

> Whitney MM, Garvine RW (2005) Wind influence on a coastal buoyant outflow. J Geophys Res Oceans 110:C03014 doi:10.1029/2003JC002261

Yokokawa T, Nagata T (2005) Growth and grazing mortality rates of phylogenetic groups of bacterioplankton in coastal marine environments. Appl Environ Microbiol 71: 6799-6807

Submitted: January 14, 2009; Accepted: June 6, 2009

Proofs received from author(s): September 8, 2009 